\title{
EMPLOYER-SIM MICROSIMULATION MODEL: MODEL DEVELOPMENT AND APPLICATION TO ESTIMATION OF TAX SUBSIDIES TO HEALTH INSURANCE
}

\author{
by \\ G. Edward Miller \\ Division of Modeling and Simulation \\ Center for Financing, Access and Cost Trends \\ Agency for Healthcare Research and Quality \\ Thomas M. Selden \\ Division of Modeling and Simulation \\ Jessica S. Banthin \\ Health and Human Resources Division Congressional \\ Budget Office
}

\section{CES 14-46 December, 2014}

The research program of the Center for Economic Studies (CES) produces a wide range of economic analyses to improve the statistical programs of the U.S. Census Bureau. Many of these analyses take the form of CES research papers. The papers have not undergone the review accorded Census Bureau publications and no endorsement should be inferred. Any opinions and conclusions expressed herein are those of the author(s) and do not necessarily represent the views of the U.S. Census Bureau. All results have been reviewed to ensure that no confidential information is disclosed. Republication in whole or part must be cleared with the authors.

To obtain information about the series, see www.census.gov/ces or contact Fariha Kamal, Editor, Discussion Papers, U.S. Census Bureau, Center for Economic Studies 2K132B, 4600 Silver Hill Road, Washington, DC 20233, CES.Papers.List@census.gov. 


\begin{abstract}
Employment-related health coverage is the predominant form of health insurance in the nonelderly, US population. Developing sound policies regarding the tax treatment of employersponsored insurance requires detailed information on the insurance benefits offered by employers as well as detailed information on the characteristics of employees and their familes. Unfortunately, no nationally representative data set contains all of the necessary elements. This paper describes the development of the Employer-Sim model which models tax-based health policies by using data on workers from the Medical Expenditure Panel Survey Household Component (MEPS HC) to form synthetic workforces for each establishment in the Medical Expenditure Panel Survey Insurance Component (MEPS IC). This paper describes the application of Employer-Sim to estimating tax subsidies to employer-sponsored health insurance and presents estimates of the cost and indcidence of the subsidy for 2008. The paper concludes by discussing other potential applications of the Employer-Sim model.
\end{abstract}




\section{Introduction}

Employment-related health coverage is the predominant form of health insurance in the nonelderly, US population covering $68.7 \%$ of adults and $58.4 \%$ of children for at least a part of the year in 2008. Current tax law provides strong subsidies to private employer-sponsored coverage as employer premium contributions and an increasing share of employee contributions are exempt from income and payroll taxes. Proposals to modify this subsidy are a perennial subject of policy debate due to their overall cost and concerns about both equity and efficiency: current subsidies primarily benefit higher income families who are the least likely to be uninsured or covered by public insurance ${ }^{1}$ and may encourage higher than optimal levels of coverage and medical care consumption ${ }^{2}$.

In recent years, the erosion of employer-sponsored private health insurance ${ }^{3}$ has led to considerable interest in a number of potential changes to the tax structure that would increase incentives for employers to offer health insurance and for individuals to purchase non-group private insurance coverage. Recently proposed changes in the tax treatment of health insurance benefits have included: capping or eliminating current subsidization of employer-sponsored insurance; providing refundable tax credits that cover all, or part, of the cost of insurance; allowing individuals to deduct insurance costs; and "pay or play" provisions that require employers to arrange for and contribute to employees' health insurance coverage (play) or pay some amount per employee to subsidize other insurance options (pay). ${ }^{4}$

\footnotetext{
${ }^{1}$ Gruber (2002); Monheit, Nichols and Selden (1995/1996); Chernew, Cutler and Keenan (2005).

${ }^{2}$ Feldstein (1973); Pauly (1986); Newhouse (1992).

${ }^{3}$ The total number of private-sector workers with employer-sponsored insurance fell from 64.2 million in 2000 to 56.1 million in 2010 (MEPS IC Summary Data Tables, http://www.meps.ahrq.gov/mepsweb/).

${ }^{4}$ For discussions of these proposals see: Furman (2008); Wilens ky and Kuttner (2008); Buchmueller, Glied, Royalty and Swartz(2008); Pauly (2008).
} 
The Patient Protection and Affordable Care Act (PPACA) that was signed into law by President Obama on March 23, 2010 changed the tax treatment of health insurance in a number of ways. Changes include tax credits for small employers ( $<25$ workers) that provide health insurance for employees and refundable premium tax credits for persons with family incomes between 133-400\% of the Federal Poverty Line to purchase insurance through newly established exchanges. PPACA also imposes an excise tax on high cost plans, with risk-adjusted thresholds determining which plans are taxed, and assesses fees on large employers (50+ workers) whose employees receive premium tax credits through insurance exchanges. ${ }^{5}$

Evaluating the impact of proposed changes and developing sound policies regarding the tax treatment of employment-related insurance requires data on employer and employee premium contributions, as well as data to support marginal tax rate simulations including each worker's income by type from all sources. Estimating the incidence of changes in tax-related health policies requires detailed information on employers (e.g., location, industry, firm size) and information on employee characteristics (e.g., total family income, assets and health status) that is representative of each establishment's entire workforce. ${ }^{6}$ Unfortunately, no single nationally representative data source contains all of these data elements, so researchers must combine information from multiple sources.

\footnotetext{
${ }^{5}$ Kaiser Family Foundation (2011a).

${ }^{6}$ The MEPS HC has detailed individual-level data that includes information on employers. These data, however, do not have information on employer premium contributions. Furthermore, the fundamental problem with relying solely on the MEPS HC to build a micro-simulation model is that data on individuals does not provide information on the nature of co-workers. It is not possible, therefore, to compute concepts such as theaverage subsidy in a worker's firm (Gruber, 2010) or to evaluatemodels of establis hment behavior (e.g., the median voter model). Each individual is, in effect, a randomly selected worker, so we cannot reliably infer that a given establishment is basing decisions on whether to offer insurance, or other similar decisions, on the observed worker's preferences.
} 
Our model uses a relatively simple approach that combines data from the Medical Expenditure Panel Survey Insurance Component (MEPS IC) ${ }^{7}$ and the MEPS Household Component (HC). In essence, we use data on workers from the MEPS HC to form synthetic workforces for each establishment in the MEPS-IC. The MEPS IC is the pre-eminent source of nationally representative data on U.S. employers and the insurance coverage they offer to their employees. The MEPS IC provides some limited perspective on each establishment's workforce, but lacks detailed information about employees and their families. At the same time, the MEPS HC provides a more comprehensive view of decision-making by workers and their families, but lacks detailed information regarding workers' establishments. To exploit the strengths of these two datasets, we refine the method developed in Selden and Gray (2006) for linking the MEPS-IC and HC data. The resulting "Employer-Sim” model provides a unique opportunity to model the dual individual/group decision-making process in establishments and to investigate a broad array of topics in the provision of employer sponsored private insurance. We believe that our method of linking the two data sets preserves, to the greatest extent possible, the correlations between establishments' and workers' characteristics and choices.

The remainder of the paper is organized as follows: The first section describes the MEPS IC and HC databases, the methods used to simulate marginal tax rates for MEPS HC workers and the data linking procedure used to develop the Employer-Sim model. The second section describes the methods used to estimate the subsidy to employer-sponsored health insurance and presents estimates for 2008. The third section describes other potential applications of the Employer-Sim model.

\footnotetext{
${ }^{7}$ The MEPS IC data are collected by the Bureau of the Census using sampling frames originating with the Internal Revenue Service. Thus, strict confidentiality rules govern access to these data. Our model was approved by the Census res earch proposal process and resides at their Res earch Data Center to take advantage of confidential MEPS IC data.
} 


\section{Development of Databases for the Employer-Sim Model}

MEPS Insurance Component. The MEPS-IC is an annual survey containing data on over 34,000 private and state and local government establishments in 2008. The survey is conducted by the U.S. Bureau of the Census under the sponsorship of the Agency for Healthcare Research and Quality (AHRQ). ${ }^{8}$ Due to the large sample size and high response rate, the MEPSIC is the leading source of data on employment-related health insurance coverage. The MEPS-IC is a stratified sample with weights that produce nationally representative estimates for a range of measures of employment-related insurance including the number of employees eligible for, and enrolled in, single, employee-plus-one, and family coverage, the employer and employee premium contributions for each type of coverage and whether employee contributions are taxpreferred under Section 125 of the Internal Revenue Code. The MEPS IC also contains detailed information on establishments including their location, industry, number of employees and whether their firm has multiple locations.

Another strength of the MEPS-IC is that it contains several key pieces of information regarding workforce characteristics including the percentages of employees who are female, age 50 and over, members of unions, low wage, medium wage and high wage. ${ }^{9}$ As is true with any employer survey, however, these workforce characteristics are not by themselves sufficient to form marginal tax rate estimates, nor do they provide information on family income, wealth, assets, health status and other worker and family characteristics that may be needed in policy or behavioral analyses. For these reasons, we supplement the MEPS-IC with data from the MEPS

\footnotetext{
${ }^{8}$ For more information see AHRQ, MEPS Methodology Reports 6, 8, and 10 and the MEPS-IC Technical Appendix. ${ }^{9}$ We used HDCOLIMP software to impute missing values for workforce characteristics and impos ed consis tency edits on imputed percentages.
} 
Household Component (MEPS-HC), in essence constructing synthetic workforces for each MEPS-IC establishment using household data on workers and their families.

MEPS Hous ehold Component. The MEPS-HC is an annual, nationally representative sample of the civilian non-institutionalized population sponsored by the Agency for Healthcare Research and Quality (AHRQ) and the National Center for Health Statistics (NCHS). ${ }^{10}$ It is a stratified and clustered random sample with weights that produce nationally representative estimates for insurance coverage, medical expenditures and a wide range of other health-related and socioeconomic characteristics. The survey has an overlapping panel design, gathering two years of data for each household over five survey rounds. We use a point-in-time sample of workers ages 16 and over in the first round of data collection. Workers are included if they are employees (wage earners) or if they are self-employed in establishments of two or more persons. ${ }^{11}$ The worker database is constructed at the job level so that individual workers appear in the data more than once if they hold multiple jobs. To obtain a sufficient sample of workers to match to the MEPS IC, we pool workers from the 2005-2007 MEPS HC. This yields an overall sample of 39,064 current main jobs and 2,655 current miscellaneous (or secondary) jobs. ${ }^{12}$ This includes 35,006 private sector jobs, 5,590 state and local government jobs and 1,123 Federal government jobs.

FEHBP Premium Data. Federal government establishments are out of scope for the MEPS IC, so we construct health insurance premiums for Federal workers in the MEPS HC

\footnotetext{
${ }^{10}$ For more information see J Cohen, et al. (1996) and S. Cohen (1997).

${ }^{11}$ This sample selection criterion matches the scope of workers included in the MEPS IC (pers onal communication with Jim Branscomb, AHRQ) and also matches the scope of workers who can be identified in the MEPS HC Person Round Plan files as holding employer-sponsored health insurance.

${ }^{12} \mathrm{~A}$ significant portion of MEPS HC employment variables for current main jobs had mis sing values that had not been previously imputed by AHRQ staff. We used HDCOLIMP software to impute mis sing values and imposed consistency and logical edits on imputed variables. Some employment variables (e.g., industry) are not recorded for current miscellaneous jobs. We imputed these characteristics fromcurrent main jobs using both person-level and job-level class variables.
} 
using data provided by the U.S. Office of Personnel Management (OPM). Specifically, we use 2004 OPM data on Federal Employees Health Benefits Program (FEHBP) premiums to calculate weighted mean premiums by state, type of worker (postal vs. non-postal) and type of coverage (individual vs. family). Next, we use information on trends in average FEHBP premiums to adjust premiums to 2008 levels. ${ }^{13}$ Finally, we merge these premiums onto MEPS HC Federal workers' records by state, type of worker ${ }^{14}$ and type of coverage.

Simulating Marginal Tax Rates. To simulate taxes for MEPS-HC workers we use the National Bureau of Economic Research (NBER) TAXSIM model. ${ }^{15}$ Marginal tax rates reflect not only each worker's earnings from their main jobs, but also earnings from miscellaneous jobs, spousal earnings, unearned income from a wide range of sources, the composition of the immediate family and home ownership. ${ }^{16}$ We compute marginal tax rates for Federal, State and Social Security/Medicare taxes over an increment to worker incomes approximately equal to the average employer contribution. ${ }^{17}$ This approach yields relevant marginal tax rates for estimates of the subsidy to employer-sponsored health insurance and reduces issues with tax "notches" that would result from evaluating smaller increments of income. Because some state government establishments have opted out of Federal Social Security (“Section 218” exemption), our simulation accounts on a state-by-state basis for the fact that these workers are not subject to Social Security taxation. We use state tax laws in effect in each state to simulate 51 State and

\footnotetext{
${ }^{13}$ Hay Group (2010).

${ }^{14} \mathrm{We}$ as sumed that all Federal workers in the Transportation industry were postal employees. The North American Industry Classification System(NAICS) classifies the industry for Postal workers as transportation and theresulting number of Postal workers in the MEPS HC, an average annual total of about 1 million, is close to other available estimates.

${ }^{15}$ For more information see Feenberg and Coutts (1993).

${ }^{16}$ Data on home ownership is obtained by linking the MEPS-HC to the National Health Interview Survey (NHIS).

${ }^{17}$ In estimating taxsubsidies we adopt the widely-used as sumption that employees who hold coveragebear the incidence of employer contributions through lower cas h wages, with incidence in proportion to the employer's contribution to the employee's held plan. To construct marginal taxrates, therefore, we add the average employer contribution to the wages of workers with coverage, simulate the additional taxes owed, and then calculate an average marginal taxrate as the change in taxes divided by the average employer contribution. The process is the same for workers without coverage except that we subtract the average employer contribution from wages.
} 
Federal marginal tax rates for each worker in the MEPS HC (e.g., we simulate marginal tax rates for each worker as if they lived in each of the 51 states in the United States).

\section{Constructing Synthetic Workforces}

We construct synthetic workforces by statistically matching MEPS HC workers to MEPS IC establishments in a process that first uses establishment level characteristics to draw a sample of workers for each establishment, then uses information on worker characteristics to fine-tune the match. Appendix A lists the variables used in each of these steps.

Drawing Synthetic Workforces. In the first step of the matching process, we use establishment-level variables that are recorded on both the MEPS IC and MEPS HC. We use these variables to draw a sample of a minimum of 300 workers from the MEPS HC who match as nearly as possible the MEPS IC establishment on industry and size, whether the firm had multiple establishments and whether the establishment offered insurance to its employees. MEPS HC workers are sampled with replacement so each worker may link to multiple establishments. Since wages are an important determinant of marginal tax rates and other worker characteristics of interest, we ensure that each sample of workers includes at least 100 low wage, 100 medium wage and 100 high wage workers. The matching process is conducted separately for private sector workers and for state and local government workers.

To match workers to establishments we use specialized matching software (HDCOLIMP $)^{18}$ that automatically creates cells, of a specified minimum size, constructed from establishment-level class variables to link donor records from the MEPS HC to recipient records in the MEPS IC. In HDCOLIMP, class variables are listed in order of priority and cells are automatically collapsed, as required for each establishment, to ensure a statistically adequate

\footnotetext{
${ }^{18}$ This software was developed by programmers at Social and Scientific Systems.
} 
pool of workers to draw from. We prioritized the class variables by examining cell frequencies and by using the MEPS HC data to examine regressions of marginal tax rates on our class variables. To create the database that we used to estimate tax subsidies, below, we used the following ordering of class variables: offer of insurance, industry, Census Region, number of employees, multiple locations, Census Division. The class variables could be reorderd or respecified to optimize the match for other worker characteristics.

State-Specific Marginal Tax Rates. As noted in the previous section, we simulate state and federal marginal tax rates for each worker using state tax laws in effect in each state. After linking workers to an establishment, we select marginal tax rates for each worker to match the establishment's state. This allows us to conduct simulations of tax-based health policies that reflect taxes in each establishment's state, even though our matching procedure allows MEPSHC workers to be drawn from outside of the establishment's state.

Raking Weight Adjus tment. Next, we implement a raking post-stratification of the MEPS-HC sampling weights within each establishment so that each establishment's synthetic workforce of MEPS-HC workers matches the establishment's reported characteristics. That is, we iteratively adjust the worker weights to align the synthetic workforce by the percentage of employees who are: female, age 50 and over, in unions, fulltime workers, low wage and high wage employees. $^{19}$ Sheils and Haught (2003) report using a similar raking strategy to form synthetic firms for their analysis of health insurance reforms. Our raking weight adjustment could, in principle, add precision by adjusting for insurance variables including the percent eligible for coverage and the percentages holding single, employee plus one and family plans.

\footnotetext{
${ }^{19}$ For a description of raking, see Kalton Flores-Cervantes, 2003.
} 
Additional variables, however, increase the chance that raked weights will exhibit considerable variability or that marginal sums will fail to converge to control totals. ${ }^{20}$

Summary Statistics. By linking the two datasets by establishment characteristics and aligning the synthetic workers using establishment workforce characteristics, we believe that our approach preserves to the maximum extent possible key correlations present in the two MEPS survey components. The resulting database augments the MEPS IC with information on employee characteristics that is representative of each establishment's entire workforce. This information can, in principle, be used to construct means, or other summary statistics, for each establishment for any MEPS-HC employee characteristic. Of course, the quality of any mean estimate for a particular establishment will depend on the strength of the correlation between that variable and the characteristics used in linking the two datasets and in raking the MEPS-HC weights. Regressions using MEPS-HC data confirmed that marginal tax rates are strongly related to many of the variables that we use to construct synthetic workforces.

Summary statistics are generated using the adjusted MEPS-HC weights for workers within each establishment. Summary statistics can be generated for all workers, or subsets of workers. For example, we calculate mean marginal tax rates for all workers and for subgroups of workers defined by insurance variables including eligibility, coverage and plan type: single, employee plus one or family. As we discuss in more detail below, in our estimates of the tax subsidy to employer-sponsored insurance, we adopt the assumption that employees who hold coverage bear the incidence of employer contributions through lower cash wages, with incidence in proportion to the employer's contribution to the employee's held plan. The ability to calculate

\footnotetext{
${ }^{20}$ Our raking procedure used sixdichotomous variables resulting in 64 cells. Additional variables rapidly increase the number of cells relative to the number of unweighted workers in the synthetic workforces. This increases the probability of empty, or sparsely populated, cells which decrease thestability of the raking algorithm(Battaglia et. al., 2004).
} 
mean marginal tax rate by type of coverage - single, employee plus one or family - is critical in the implementation of this assumption.

Benchmarking-Calibration by Sector. Although the MEPS IC and HC contain similar information on establishments and workforces, there are differences in both the unit of observation (establishment vs individual) and the nature of reporting (e.g., individual's estimate of the number of employees in an establishment vs. human resources knowledge of payroll). The quality of our linking procedure depends in part on a strong correspondence between MEPS HC and IC data (e.g., evidence that variables are measuring similar concepts). One test of this correspondence is to compare estimates of the total number of workers in the MEPS HC and the MEPS IC overall and by subgroups defined by the variables used in the matching process. Appendices B1 and B2 present these comparisons for the private and state and local sectors, respectively.

The estimate of the total number of active workers in the private sector in the United States was about 5.5 percent lower in the 2008 MEPS IC (116.1 million) than the average annual estimate from the 2005-2007 MEPS HC (122.8 million). Similarly, the estimate of the total number of active workers in state and local governments was about 6.3 percent lower in the 2008 MEPS IC (19.6 million) than in the average annual estimate from the 2005-2007 MEPS HC (20.9 million). The third columns of Appendices B1 and B2 present the ratios of MEPS IC estimates to adjusted MEPS HC estimates by individual-level and establishment level characteristics. In calculating these ratios, we adjust MEPS HC estimates to account for the differences in estimates of totals across the two surveys.

Results show a strong correspondence across the MEPS IC and HC in the distributions of workers by individual-level socioeconomic characteristics (sex, age, union status, wage) and 
location (Census Region, Census Division) and a fairly strong correspondence by insurance status (eligibility, any coverage, type of coverage). By contrast, the correspondence in the distributions of workers by establishment characteristics (offers of insurance, number of employees, industry and multi-location status) show greater differences across the two surveys. These results suggest, as one might expect, that household reports of individual characteristics are somewhat more reliable than household reports of establishment characteristics. Results also further highlight the value of raking MEPS HC workers' weights to align the characteristics of synthetic workforces with those reported by MEPS IC establishments.

It is common practice for micro-simulation models to calibrate databases to control totals in large nationally representative databases. In the Employer_Sim model calibration of data for the private and state and local sectors is not necessary because: 1) the MEPS IC is the preeminent nationally representative source of information on premiums for and enrollment in employer-sponsored insurance in these sectors and 2) Employer-Sim model estimates are produced using MEPS IC sample weights and design parameters.

The situation is different for Federal government establishments which are out of scope for the MEPS IC. We estimate Federal sector subsidies using MEPS HC data, but we calibrate MEPS HC weights by type of worker (postal vs. non-postal) and insurance status to match totals reported by the Office of Personnel Management (OPM). ${ }^{21}$

Other Recent Models. Two recent models use alternative approaches to developing databases which are designed, in part, to study the tax exclusion for employer-sponsored health insurance. A central component of both models is the construction of a database containing information on the full distribution of worker characteristics in each firm. Gruber (2010) builds

\footnotetext{
${ }^{21}$ See OPM tables at http://www.opm.gov/feddata/HistoricalTables/TotalGovernmentSince1962.asp
} 
synthetic firms in the CPS by assigning each CPS worker a set of 99 co-workers that are selected to represent the likely true set of co-workers in that firm. The selection of likely coworkers is based on Bureau of Labor Statistics data that provide information on the earnings distribution of co-workers for a worker with a given level of earnings by firm size, region of the country, and health insurance offering status. Rather than construct synthetic firms, Gillette and Hunter, et. al. (2010) use population tax data from the 2004 IRS Compliance Data Warehouse (CDW) to exactly match employees to firms and to obtain Federal and Social Security/Medicare marginal tax rates for all employees. Both of these models use MEPS HC insurance and expenditure data to construct employer-sponsored premiums for groups of workers in firms and for individuals in the nongroup market. ${ }^{22}$

\section{Estimating the Subsidy to Employer Sponsored Health Insurance}

This section describes methods that were first used to estimate the tax subsidy to health insurance for $2006^{23}$ and which we have modified and updated to estimate subsidies for 2008. In the Employer-Sim model, we estimate the tax subsidy to employer-sponsored insurance in terms of the "tax expenditure", or the total dollar amount of foregone revenue. We assume that employer premium contributions are shifted forward to workers in the form of lower cash wages and, therefore, use workers' marginal tax rates to value the subsidy. ${ }^{24}$ The per worker subsidy is given in Equation 1:

\footnotetext{
${ }^{22}$ The need to construct premiums arises for a couple of reasons. First, these models do not have a direct link to the MEPS IC, or another source of premiums. Second, both models simulate changes in insurance coverage resulting from changes in taxpolicy. This requires information on premiums for held coverage as well as premiums for potential alternative coverage.

${ }^{23}$ Selden and Gray (2006) used 2002 MEPS IC data and projected estimates to 2006.

${ }^{24}$ For a review of the literature on the forward shifting of employer contributions see Pauly (2001).
} 


$$
\text { (1) Tax Subsidy }=\left[\frac{\left(t^{F E D}+t^{S T}+2 * t^{S S}\right)}{\left(1+t^{S S}\right)}\right] \pi
$$

where $\pi$ is the full premium and $t^{F E D}, t^{S T}$, and $t^{S S}$ are marginal tax rates for Federal income, State income, and Social Security/Medicare. (See Appendix C for a derivation of the tax subsidy in Equation 1).

Equation 1 presents the simplified case in which employee premium contributions are tax preferred (as most are). Similar expressions handle the case in which only employer contributions are tax preferred. Equation 1 represents the tax subsidy to workers as workers' compensation is shifted from taxed wages to untaxed insurance premiums holding total compensation constant. The numerator is foregone tax revenue (including the employee and employer share of the Social Security/Medicare tax) for each one dollar reduction in wages. The denominator results from the tradeoff between wages and premiums. Since employers pay Social Security/Medicare taxes on wages they are indifferent between paying 1 dollar in wages or paying $\left(1+\mathrm{t}^{\mathrm{ss}}\right)$ dollars in premiums.

We use MEPS IC-HC linked data to develop tax subsidy estimates for private sector workers and state and local government workers. Federal establishments are out of scope for the MEPS IC, so we develop tax subsidy estimates for the Federal sector using the MEPS-HC distribution of Federal employees combined with the FEHBP premium information described above. $^{25}$

Estimating tax subsidies requires assumptions regarding how the incidence of employer premium contributions is distributed across workers in a firm. Our approach adopts the widely-

\footnotetext{
${ }^{25}$ In this paper, we present preliminary estimates of aggregate subsidies in the Federal sector, but do not present per worker estimates.
} 
used assumption that employees who hold coverage bear the incidence of employer contributions through lower cash wages, with incidence in proportion to the employer's contribution to the employee's held plan. Specifically, we estimate subsidies using enrollment weighted means of premiums for single, employee plus one and family plans and enrollment weighted mean marginal tax rates among employees who hold each type of plan. ${ }^{26}$

We use IC sample weights to generate tax subsidy estimates that are nationally representative for all active employees in US establishments. All standard errors and statistical tests are adjusted to account for the complex design of the MEPS-IC. ${ }^{27}$

\section{Results: Tax Subsidy Estimates for 2008.}

The total tax subsidy for employer sponsored health insurance for active workers in the U.S. civilian, non-institutionalized population was \$214.1 billion in 2008 (Table One). More than three-quarters (\$168.2 billion) of the subsidy went to the 116.1 million workers in the private sector, \$38.4 billion went to the 19.6 million workers in state and local governments and the remaining $\$ 7.5$ billion went to the 2.8 million civilian, federal workers. The federal income tax component accounted for more than half (\$114.6 billion) of the subsidy, FICA and Medicare taxes accounted for about one-third (\$73.8 billion) of the subsidy, and the state and local tax component accounted for the remaining $\$ 25.8$ billion, or about 12 percent of the subsidy.

Table Two presents average tax subsidies per worker by insurance status for workers in the private and state and local sectors. As expected, subsidies show large variations across groups defined by insurance eligibility, coverage, and type of coverage. The average subsidy for all private sector workers (regardless of eligibility or insurance status), was $\$ 1,448$ while the average subsidies among eligible workers and insured workers were \$2,113 and \$2,687,

\footnotetext{
${ }^{26}$ For a discussion of the incidence of health insurance premiums see Selden and Bernard (2004).

${ }^{27}$ More technically, we use employee rather than establishment weights throughout the analysis. Our estimates exclude railroad establishments due to concerns involving confidentiality.
} 
respectively. Among insured workers, those with non-single coverage, which included family and employee plus one policies, had average subsidies of $\$ 3,841$, about two and a half times the average subsidy of $\$ 1,543$ for those with single coverage. We found similar variations in subsidies by eligibility and insurance status in the state and local sector.

As we discuss above, we believe that our method of linking the MEPS HC and IC preserves, to the greatest extent possible, the correlations between establishments' and workers' characteristics and choices. In Table Three we take advantage of this aspect of our database by examining tax subsidies across groups of private-sector establishments defined by firm size, percent full time workers, wage rate, industry and Census division. For each group we present estimates of the average subsidy per worker - which captures differences in coverage, marginal tax rates and premiums - and average subsidies per covered worker, which focuses attention on differences in marginal tax rates and premiums. We also present information on the percent of workers eligible for coverage, take-up conditional on eligiblity and tax subsidies as a percent of premiums. .

Sector. The first two rows of Table Three examine overall subsidies in the private and state and local government sectors. Results show that average subsidies per worker are about 35 percent higher in the state and local sector $(\$ 1,958)$ than in the private sector $(\$ 1,448)$. The primary reasons for this difference are that state and local employees are more likely than private sector employees to be eligible for insurance (76.2 vs. 68.5 percent) and, conditional on eligiblity, are more likely to take-up insurance coverage (86.1 vs. 78.7 percent). The average tax subsidy per covered employee is also higher in the state and local sector (\$2,984 vs. \$2,687) which may reflect more generous benefits, or a higher proportion of family vs. single coverage. The tax subsidy as percent of premiums is lower in the state and local than in the private sector 
(32.9 vs. 35.1 percent). One reason for the lower percentage in the state and local sector is that many workers do not pay Social Security taxes due to Section 218 exemptions.

Firm size. Results show that subsidies in the private sector disproportionately flow to workers in large firms. The average subsidy per worker in firms with 1,000 or more employees is $\$ 1,815$, which is more than two and a half times the $\$ 679$ subsidy per worker in firms with fewer than ten employees. The primary reason for this difference is that the percentage of workers eligible for insurance coverage increases with firm size, from a low of 37.0 percent for workers in the smallest firms to 78.6 percent for workers in the largest firms. Workers in the largest firms also have higher average subsidy rates per premium dollar than workers in the smallest firms 35.7 percent vs. 33.1 percent - and larger average subsidies per covered worker $-\$ 2,880$ vs. $\$ 2,319$.

Full-time versus part-time. Differences in the average subsidy per worker are even larger when we compare establishments by the percentage of full time versus part time workers. In establishments where less than 25 percent of all workers work full time, only 21.7 percent of workers are eligible for insurance coverage, the average subsidy per covered worker is $\$ 2,177$ and the average subsidy per worker, regardless of coverage, is \$304. By contrast, in establishments where more than 75 percent of workers work full time, 79.2 percent of workers are eligible for insurance, the average subsidy per covered worker is $\$ 2,738$ and the average subsidy per worker is $\$ 1,759$ - almost six times the average subsidy in establishments where less than 25 percent of workers are full time.

Wage Rates. Tax subsidies disproportionately benefit higher-income workers who have higher marginal tax rates, higher coverage rates, and higher premiums. In predominantly highwage establishments, the per worker subsidy is $\$ 2,305$, and the subsidy per covered worker is 
\$3,176. By contrast, in establishments where more than 50 percent of workers are low-wage, the average subsidy per worker is $\$ 677$ - less than one-third the level in predominantly high-wage establishments - and the subsidy per covered worker is $\$ 2,216 .^{28}$

Industries. Tax subsidies also show substantial variation across industries in the private sector. The industries with the lowest per worker tax subsidies (ranging from $\$ 623$ to $\$ 899$ ) are agriculture, fisheries, and forestry; other services; and retail trade. Construction workers have a somewhat larger average subsidy of $\$ 1,131$. In the remaining industry categories, however, subsidies per worker range from $\$ 1,757$ to $\$ 2,098$. The percentages of employees eligible for insurance (which range from 35.9 to 87.9 percent) and average subsidies per covered worker (which range from $\$ 1,974$ to $\$ 2,938$ ) both play a significant role in differences in subsidies across industry groups. The higher subsidies per covered worker may reflect more generous benefits, or a higher proportion of family vs. single coverage, but marginal tax rates also play a role as evidenced by the tax subsidies per premium dollar which vary across industries from a low of 31.8 percent to a high of 36.0 percent.

Census Division. Tax subsidies range from a low of $\$ 1,181$ per worker in the West South Central division to a high of $\$ 1,750$ in New England. Differences in eligibility (64.9 vs. 70.8 percent) and subsidies per covered worker $(\$ 2,304$ to $\$ 3,176)$ both contribute to differences between these divisions. Again, marginal tax rates play a role in generating differences in subsidies per covered worker as tax subsidies as a percent of premiums are significantly higher in New England (36.5 percent) than in West South Central (32.1 percent).

Multivariate results. In Table Four, we use weighted linear regressions to further examine the distribution of tax subsidies in the private sector. The first model (Column 1) examines

\footnotetext{
${ }^{28}$ In the MEPS IC, workers are categorized as low wage if they make less than $\$ 11.00$ per hour and are categorized as high wage if they make more than $\$ 25.50$ per hour.
} 
average subsidies per worker and is weighted by the number of employees in each establishment. Results show that the large differences in average subsidies per worker by firm size, percent full time, wage rate and industry persist in multivariate models and are consistent with our descriptive findings. Differences across Census divisions are somewhat attenuated, but are still statistically significant. The second model (Column 2) examines average subsidies per covered workers and is weighted by the number of employees enrolled in insurance. In general, coefficients in our second model, which examines subsidies per covered worker, are in the same direction, but are smaller than coefficients in our first model, which examines subsidies per worker regardless of coverage. This is not surprising since differences in subsidies per worker reflect differences in eligibility, conditional take-up, benefit generosity and marginal tax rates, while differences in subsidies per covered worker reflect only the latter two factors - benefit generosity and marginal tax rates. Results also suggest, however, that establishments with a higher percentage of eligible employees, tend to offer more generous coverage than establishments with lower percentages of eligible employees.

Limitations. Several important caveats should be considered in evaluating EmployerSim estimates of tax subsidies. First, the model assumes that employer premium contributions are shifted forward to workers in the form of lower cash wages, thereby justifying our use of worker marginal tax rates to value the subsidy. Second, our results may be sensitive to our assumption that employees who hold coverage bear the incidence of employer contributions through lower cash wages, with incidence in proportion to the employer's contribution to the employee's held plan. Future work with Employer-Sim will test the sensitivity of results to alternative incidence assumptions. Third, estimates apply only to active employees. Retiree coverage and self-employment coverage, for individuals in single-person firms, are not included 
in our model. Fourth, we focus solely on the tax subsidy for employer-provided insurance. Currently our model estimates do not include tax subsidies on contributions to health savings accounts or on medical expenditures paid through flexible savings accounts. Our estimates also exclude the tax subsidy for deductible medical expenditures in excess of 7.5 percent of adjusted gross income.

By focusing solely on employment-related coverage of workers, Employer-Sim provides the largest, but not the only piece of the puzzle. ${ }^{29}$ It is important to bear in mind that any change in the tax treatment of employment-related health insurance would likely affect these other subsidies. In particular, we do not adjust our estimates for the likely increase in excess medical expense deduction that would occur if the tax subsidy were removed entirely while leaving the existing itemization rules intact. We believe our approach is the appropriate method when studying the magnitude and distribution of the tax subsidy - in contrast to analyzing the budgetary impact of a specific legislative proposal.

\section{Other Applications of the Employer-Sim Model}

Projecting Data. The estimates in this paper use 2008 MEPS IC data to estimate tax subsidies for 2008. To obtain tax subsidy estimates for the current year we could project our synthetic database to 2011. We could begin with 2008 MEPS IC data, or use 2010 MEPS IC data which recently became available. Regardless of which data year we use, projecting the data forward would comprise several major steps. First, we would adjust the MEPS-IC sampling weights to reflect changes between the MEPS IC data year and 2011 in total employment and in the percentage of employees who were insured using separate adjustment factors for the private, State and Local government, and Federal sectors, by single versus non-single coverage. Next,

\footnotetext{
${ }^{29}$ For estimates of these other taxexpenditures as of 2004, see Sheils Haught (2004).
} 
we would adjust premiums for single and non single plans to account for premium growth. Finally, we would use TAXSIM to produce marginal tax rates for the current year.

All data required to project our database to 2011 are currently available. Employment growth factors are available with only a one month lag from the Bureau of Labor Statistics. ${ }^{30}$ Factors to adjust the percentage of workers with single and non-single coverage and to inflate premiums are currently available from Kaiser/HRET through $2011 .^{31}$

Alternative Incidence Assumptions. As we discuss above, our basic approach to estimating tax subsidies adopts the widely-used assumption that employees who hold coverage bear the incidence of employer contributions through lower cash wages, with incidence in proportion to the employer's contribution to the employee's held plan. While this simplifies the analysis, many economists subscribe to more nuanced theories of incidence. For instance, it may well be that employees experience cash wage offsets from employer contributions if they are offered coverage - whether or not they take up the coverage offered. Or, it may be that cash wage offsets reflect not only eligibility, but also the likelihood of enrollment. For example, lowwage workers who have low take-up rates might have relatively smaller cash wage offsets. Incidence might also reflect observable risk factors, such as age, sex, body mass index, and past utilization. Building on Selden and Bernard’s (2004) analysis of MEPS HC data, Employer-Sim will enable us to explore the impact of alternative assumptions regarding the incidence of employer contributions on the aggregate tax expenditure and its incidence across subgroups of the population. The ability to model alternative incidence assumptions may also shed insight into the distribution of gains and losses from reforms in this market.

\footnotetext{
${ }^{30}$ Bureau of Labor Statistics, Current Employment Statistics.

${ }^{31}$ The Kaiser Family Foundation and Health Research and Educational Trust, Employer Health Benefits Annual Survey: 2011. (Washington: The Henry J. Kaiser Family Foundation).
} 
Changes in Tax Treatment of ESI. In addition to providing estimates of tax subsidies to employer-sponsored health insurance, under current law, Employer-Sim can also be used to examine the effects of polices that would change the tax treatment of health insurance. A direct extension of our initial modeling work would be to simulate the effect of capping the tax exclusion on tax revenues (and on the tax subsidy). The simplest case would be a "statutory tax incidence analysis" in which we would simulate a change in tax rules, but hold all other establishment and individual behavior constant. Caps on exclusions could, potentially, be formulated in a number of different ways. A cap could be linked to worker pay (as with the payroll tax) so that workers making more than a set threshold would be required to pay taxes on health benefits. Alternatively, a cap could be formulated in terms of the amount of premiums that could be excluded per worker (with separate limits for single, employee plus one, and family plans). The MEPS IC-HC data would provide the flexibility to examine a wide range of subsidy caps.

Tax-Price Elasticities. Employer-Sim may also prove to be a valuable resource for behavioral research into the effect of tax subsidies on the offer and take-up of coverage. The "tax price" of health insurance, which is simply calculated as 1 minus the tax subsidy, formalizes the cost of insurance in terms of (after-tax) consumption of spending a dollar on premiums:

$$
\text { (2) } \mathrm{TP}(\underline{\mathrm{t}})=\frac{\left(1-\mathrm{t}^{\mathrm{FED}}-\mathrm{t}^{\mathrm{ST}}-\mathrm{t}^{\mathrm{SS}}\right)}{\left(1+\mathrm{t}^{\mathrm{SS}}\right)}
$$

where $t^{F E D}, t^{S T}$, and $t^{S S}$ are marginal tax rates as defined above. ${ }^{32}$ Intuitively, $t^{S S}$ enters equation (2) twice because employers and employees both contribute toward payroll taxation.

\footnotetext{
${ }^{32}$ See, for instance, Gruber and Poterba(1996a,b).
} 
One general objective of our research would be to examine establishment and employee behavior as a function of $T P$, reflecting the widely-held belief among economists that firms' decisions to offer health insurance are based, in part, on the extent to which health insurance is tax preferred for employers and/or their employees. ${ }^{33}$ By linking MEPS IC and HC data, Employer-Sim may also offer insights into non-tax-related factors affecting firm decisions, such as (i) the relationship between offering insurance and the percentage of workers with offers from spouses at other companies and/or (ii) the percentage of employees' children who are eligible for public coverage. Finally, TP could be used as a means of evaluating firms' responses to changes in tax-based policies. For example, we would simulate the effects of a subsidy cap on establishments' offers of insurance by first simulating the effect of the subsidy cap on the tax price and then using estimated elasticities of firms' responsiveness to $T P$ to simulate changes in establishments’ behavior.

\section{Conclusion}

Employer-sponsored insurance will likely continue to be the primary source of health insurance coverage in the United States for nonelderly individuals and families for the foreseeable future. As a result, the cost and incidence of the tax subsidy to employer-sponsored insurance will continue to be a subject of policy debate. The recently passed Patient Protection and Affordable Care Act changes the tax treatment of health insurance in a number of ways including the provision of tax credits to small employers who offer insurance to employees and the imposition of excise taxes on high cost plans.

The central role of ESI and related tax policies in the provision of healthcare in the United States underscores the need for databases that can provide baseline estimates of the cost

\footnotetext{
${ }^{33}$ See, for instance, Gruber (2002), Bernard and Selden (2003), Chernew, Cutler, and Keenan (2005a,b), and Royalty (2000).
} 
and incidence of tax subsidies and provide information on the potential implications of reforms. Unfortunately, no single nationally representative database contains all information necessary to examine tax-based health insurance policies. The Employer-Sim model leverages existing data to construct a unique, high quality database that can be used to examine a broad array of issues related to employer-sponsored insurance. 


\section{References}

Agency for Healthcare Research and Quality, MEPS Methodology Reports 6, 8, and 10. Available under MEPS publications at http://www.meps.ahrq.gov/Data_Public.htm

Agency for Healthcare Research and Quality, MEPS-IC Technical Appendix at http:/www.meps.ahrq.gov/MEPSDATA/ic/2002/techappendix.htm

Antos J, G Wilensky and H Kuttner. (2008). The Obama Plan: More Regulation, Unsustainable Spending. Health Affairs 27(6): w462-471.

Battaglia MP, Izrael D, Hoaglin DC and Frankel MR. (2004). Tips and Tricks for Raking Survey Data (a.k.a. Sample Balancing), American Association for Public Opinion Research, 4740-4744: http://www.amstat.org/sections/srms/Proceedings/y2004/files/Jsm2004-000074.pdf

Bernard D and TM Selden. (2003). Employer Offers, Private Coverage, and the Tax Subsidy for Health Insurance: 1987 and 1996, International Journal of Health Care Finance and Economics, 2: 297-318.

Buchmueller T, SA Glied , A Royalty and K Swartz. (2008). Cost and Coverage Implications of the McCain Plan to Restructure Health Insurance. Health Affairs 27(6): w472-481.

Chernew M, DM Cutler, and PS Keenan. (2005a). Charity Care, Risk Pooling, and the Decline in Private Health Insurance. American Economic Review, Papers and Proceedings, 95(2): 209-213.

Chernew M, DM Cutler and PS Keenan. (2005b). Increasing Health Insurance Costs and the Decline in Insurance Coverage. Health Services Research 40(4): 1021-39.

Cohen J, et al. (1996). "The Medical Expenditure Panel Survey: A National Health Information Resource," Inquiry, Winter: pp. 373-389.

Cohen S. (1997). "Sample Design of the 1996 Medical Expenditure Panel Survey Household Component,” MEPS Methodology Report No. 2, Pub. No. 97-0027 (Rockville, MD: Agency for Health Care Policy and Research).

Democratic Policy Committee. (2010). The Patient Protection and Affordable Care Act: Detailed Summary. http://dpc.senate.gov/healthreformbill/healthbill04.pdf

Feenberg, D and E Coutts. (1993). “An Introduction to the TAXSIM Model,” Journal of Policy Analysis and Management, v. 12, n. 1 (Winter) 189-194.

Furman J. (2008). Health Reform Through Tax Reform: A Primer. Health Affairs 27(3): 622632. 
Gillette, Robert, Gillian Hunter, Ithai Z. Lurie, Jonathan Siegel and Gerald Silverstein. (2010). "The Impact of Repealing the Exclusion for Employer-Sponsored Insurance". National Tax Journal, December 2010, 63 (4, Part 1), 695-708.

Glied S, DK Remler and JG Zivin. (2002). Inside the Sausage Factory: Improving Estimates of the Effects of Health Insurance Expansion Proposals. The Millbank Quarterly, 80(4): 603-635

Gruber J. (2002). The Impact of the Tax System on Health Insurance Coverage. International Journal of Health Care Finance and Economics, 1: 293-304.

Gruber J. (2010). The Tax Exclusion for Employer-Sponsored Health Insurance. NBER Working Paper\#15766. http:/www.nber.org/papers/w15766

Gruber J and R McKnight. (2003). Why Did Employee Health Insurance Contributions Rise? Journal of Health Economics, 22(6): 1085-1104.

Gruber J and E Washington. (2004). Subsidies to Employee Health Insurance Premiums and the Health Insurance Market. Journal of Health Economics 24: 253-276.

Gruber J and M Lettau. (2004). How Elastic is the Firm's Demand for Health Insurance? Journal of Public Economics 88: 1273-1293.

Gruber J and JM. Poterba. (1996a). Tax Subsidies to Employer-Provided Health Insurance. in Empirical Foundations of Household Taxation, edited by Martin Feldstein and James M. Poterba. (The University of Chicago Press: Chicago).

Gruber J and JM Poterba. (1996b). Fundamental Tax Reform and Employer-Provided Health Insurance., in Economic Effects of Fundamental Tax Reform, edited by Henry J. Aaron and William G. Gale (The Brookings Institution Press: Washington, D.C.).

Hay Group (2010). Trends in Health Premiums: From the Hay Benefits Prevalence Report and the Federal Employees Health Benefits Program, 1981 through 2010. http://www.haygroup.com/downloads/us/Trend2010_-_FINAL.pdf

Kalton G and I Flores-Cervantes. (2003). Weighting methods. Journal of Official Statistics 19: 81-97.

Kaiser Family Foundation (2011a). Focus on Health Reform: Summary of New Health Reform Law. Last modified on April 15, 2011. http:/www.kff.org/healthreform/upload/8061.pdf

Kaiser Family Foundation (2011b). Employer Health Benefits: 2011 Summary of Findings. http://ehbs.kff.org/pdf/8226.pdf

Office of Personnel Management. (2007). Federal Civilian Workforce Statistics: The Fact Book: 2007 Edition. http://www.opm.gov/feddata/factbook/ 
Pauly M and B Herring. (2001). Expanding Coverage Via Tax Credits: Trade-Offs and Outcomes. Health Affairs 20(1): 9-26.

Pauly M. (2001). Making Sense of a Complex System: Empirical Studies of Employment-Based Health Insurance, International Journal of Health Care Finance and Economics 1: pp. 333-339.

Pauly M. (2008). Blending Better Ingredients for Health Reform. Health Affairs 27(6): w482491.

Selden TM and Bernard DM. (2004). Tax Incidence and Net Benefits in the Market for Employment-Related Insurance: Sensitivity of Estimates to the Incidence of Employer Costs. International Journal of Health Care Finance and Economics, 4: 167-192.

Selden TM and BM Gray. (2006). Tax Subsidies for Employment-Related Health Insurance: Simulation Results for 2006 from the Medical Expenditure Panel Survey. Health Affairs, 25(6):1568-1579.

Selden TM. (2009). The Impact of Increased Tax Subsidies on the Insurance Coverage of SelfEmployed Families: Evidence from the 1996-2004 Medical Expenditure Panel Survey. Journal of Human Resources. 44(1): 115-139.

Sheils J and R Haught. (2003). "Cost and Coverage Analysis of Ten Proposals to Expand Health Insurance Coverage,” Report to the Robert Wood Johnson Foundation (Falls Church, VA: Lewin Group,October).

Sheils J and Haught R. (2004). The Cost of Tax-Exempt Health Benefits in 2004, Health Affairs, Web Exclusive (25 February 2004): W4-106 - W4-112.

Royalty AB. (2000). Tax Preferences for Fringe Benefits and Worker's Eligibility for Employer Health Insurance. Journal of Public Economics, 75: 209-227. 
Table One

Aggregate Tax Expenditure For Employment-Related Group Coverage of Current Workers in Private and Public Establishments, 2008

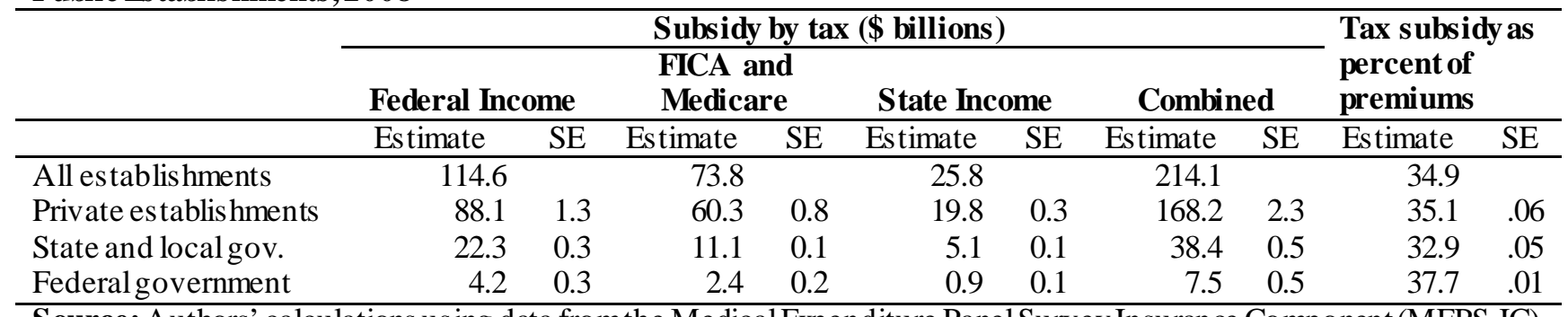

Source: Authors’ calculations using data from the Medical Expenditure Panel Survey Insurance Component(MEPS-IC) and Hous ehold Component (MEPS-HC) and Federal Employment Health Benefits (FEHBP) premium data.

Notes:

1. Estimates were constructed using worker-level, not establishment, sampling weights.

2. For private and state-local government estimates, standard errors reflect sampling error in MEPS-IC. No adjustment is made for sampling variation in constructing synthetic workforces.

3. The MEPS-IC contains data on 31,073 private and 2,755 public establishments after excluding railroads because of concerns involving confidentiality.

4. Standard errors for Federal government estimates reflect sampling variation in the MEPS-HC.

5. Estimates for “All Establishments” are sums of separate estimates fromMEPS-IC and MEPS-HC. Standard errors were not available for these estimates. 
Table Two

Average Tax Subsidy Per Employee by Take-Up, 2008

\begin{tabular}{|c|c|c|c|c|c|c|c|c|c|c|}
\hline & \multicolumn{8}{|c|}{ Subsidy by tax (\$ billions) } & \multirow{2}{*}{\multicolumn{2}{|c|}{$\begin{array}{l}\text { Tax subsidy } \\
\text { as percent of } \\
\text { premiums }\end{array}$}} \\
\hline & \multicolumn{2}{|c|}{$\begin{array}{l}\text { Federal } \\
\text { Income }\end{array}$} & \multicolumn{2}{|c|}{$\begin{array}{l}\text { FICA and } \\
\text { Medicare }\end{array}$} & \multicolumn{2}{|c|}{ State Income } & \multicolumn{2}{|c|}{ Combined } & & \\
\hline & Estimate & $\mathrm{SE}$ & Estimate & $\mathrm{SE}$ & Estimate & SE & Estimate & SE & Estimate & $\mathrm{SE}$ \\
\hline & \multicolumn{10}{|c|}{ Private Sector } \\
\hline All Workers & 759 & 9 & 519 & 5 & 170 & 2 & 1,448 & 14 & 35.1 & .06 \\
\hline Eligible workers & 1,107 & 9 & 758 & 5 & 249 & 3 & 2,113 & 16 & 35.1 & .06 \\
\hline Insured workers & 1,407 & 9 & 964 & 5 & 316 & 4 & 2,687 & 16 & 35.1 & .06 \\
\hline With single coverage. & 786 & 4 & 579 & 3 & 179 & 2 & 1,543 & 8 & 35.2 & .06 \\
\hline With nonsingle cov. & 2,034 & 14 & 1,352 & 8 & 455 & 6 & 3,841 & 24 & 35.1 & .07 \\
\hline & \multicolumn{10}{|c|}{ State and Local Government } \\
\hline All W & 1,134 & 8 & 563 & 5 & 261 & 3 & 1,958 & 15 & 32.9 & .05 \\
\hline Eligible workers & 1,488 & 10 & 739 & 6 & 342 & 3 & 2,569 & 17 & 32.9 & .05 \\
\hline Insured workers & 1,728 & 9 & 858 & 6 & 397 & 3 & 2,983 & 16 & 32.9 & .05 \\
\hline With single coverage & 1,022 & 7 & 522 & 4 & 217 & 3 & 1,762 & 12 & 32.8 & .06 \\
\hline With nonsingle cov. & 2,297 & 13 & 1,129 & 9 & 543 & 4 & 3,970 & 22 & 33.0 & .06 \\
\hline
\end{tabular}

Source: Authors' calculations using data from the Medical Expenditure Panel Survey Insurance Component (MEPS-IC) and Household Component (MEPS-HC).

Notes:

1. Estimates were constructed using worker-level, not establishment, sampling weights.

2. Standard errors reflect sampling error in the MEPS-IC. No adjustment is made for sampling variation in constructing synthetic workforces.

3. The MEPS-IC contains data on 31,073 private and 2,755 public establis hments after excluding railroads because of concerns involving confidentiality. 
Table Three

Eligibility, Take-Up, and Average Tax Subsidy Per Employee, By SelectedEs tablishment Characteristics, 2008

\begin{tabular}{|c|c|c|c|c|c|c|c|c|c|c|}
\hline & \multicolumn{2}{|c|}{$\begin{array}{c}\text { Percent of } \\
\text { employees } \\
\text { eligible for } \\
\text { coverage }\end{array}$} & \multicolumn{2}{|c|}{$\begin{array}{c}\text { Percent of } \\
\text { eligible employees } \\
\text { enrolled }\end{array}$} & \multicolumn{2}{|c|}{$\begin{array}{c}\text { Average tax subsidy } \\
\text { per employee (\$) }\end{array}$} & \multicolumn{2}{|c|}{$\begin{array}{c}\text { Average tax } \\
\text { subsidy per covered } \\
\text { employee }(\$)\end{array}$} & \multicolumn{2}{|c|}{$\begin{array}{l}\text { Tax subsidy as } \\
\text { percent of } \\
\text { premiums }\end{array}$} \\
\hline & Estimate & SE & Estimate & $\mathrm{SE}$ & Estimate & SE & Estimate & $\mathrm{SE}$ & Estimate & $\mathrm{SE}$ \\
\hline State and local governments & 76.2 & 0.3 & 86.1 & 0.2 & 1,958 & 15 & 2,984 & 16 & 32.9 & \\
\hline \multirow[t]{2}{*}{ Private sector } & 68.5 & 0.4 & 78.7 & 0.3 & 1,448 & 14 & 2,687 & 16 & 35.1 & 0.06 \\
\hline & \multicolumn{10}{|c|}{ Private Sector by Firm and Establishment Characteristics } \\
\hline \multicolumn{11}{|l|}{ Firm size (\# of workers) } \\
\hline$<10$ & 37.0 & 0.6 & 79.2 & 0.6 & 679 & 14 & 2,319 & 30 & 33.1 & 0.18 \\
\hline $10-24$ & 54.5 & 1.0 & 74.3 & 0.7 & 915 & 24 & 2,261 & 37 & 32.7 & 0.27 \\
\hline $25-99$ & 64.1 & 0.9 & 74.8 & 0.6 & 1,115 & 23 & 2,325 & 31 & 34.2 & 0.18 \\
\hline $100-999$ & 72.4 & 0.9 & 78.4 & 0.6 & 1,496 & 28 & 2,636 & 29 & 35.3 & 0.11 \\
\hline 1000 or more & 78.6 & 0.7 & 80.2 & 0.4 & 1,815 & 26 & 2,880 & 26 & 35.7 & 0.08 \\
\hline \multicolumn{11}{|l|}{ Percent full-time workers } \\
\hline$<25 \%$ & 21.7 & 1.9 & 64.4 & 3.3 & 304 & 40 & 2,177 & 54 & 34.0 & 0.45 \\
\hline $25-49 \%$ & 37.9 & 1.1 & 60.7 & 1.6 & 566 & 27 & 2,461 & 46 & 34.1 & 0.21 \\
\hline $50-74 \%$ & 57.8 & 0.8 & 72.2 & 0.8 & 1,031 & 27 & 2,471 & 44 & 34.6 & 0.17 \\
\hline $75 \%+$ & 79.2 & 0.4 & 81.1 & 0.3 & 1,759 & 17 & 2,738 & 19 & 35.3 & 0.07 \\
\hline \multicolumn{11}{|l|}{ Wage rate } \\
\hline$>50 \%$ low wage & 47.0 & 0.8 & 65.1 & 0.8 & 677 & 19 & 2,216 & 33 & 32.6 & 0.15 \\
\hline$>50 \%$ medium wage & 74.8 & 0.5 & 80.9 & 0.3 & 1,600 & 20 & 2,647 & 21 & 35.0 & 0.07 \\
\hline$>50 \%$ high wage & 84.3 & 1.1 & 86.1 & 0.6 & 2,305 & 46 & 3,176 & 44 & 37.0 & 0.14 \\
\hline Other firms & 72.4 & 1.1 & 79.1 & 0.8 & 1,532 & 41 & 2,673 & 51 & 35.2 & 0.21 \\
\hline \multicolumn{11}{|l|}{ Industry } \\
\hline Agriculture/fish/forestry & 35.9 & 5.6 & 88.0 & 3.6 & 623 & 111 & 1,974 & 200 & 31.8 & 1.52 \\
\hline Mining, manufacturing & 87.9 & 0.7 & 84.8 & 0.5 & 2,098 & 37 & 2,813 & 39 & 35.4 & 0.12 \\
\hline Construction & 62.6 & 1.3 & 78.8 & 1.1 & 1,131 & 36 & 2,293 & 47 & 33.4 & 0.30 \\
\hline Utilities, transportation & 79.8 & 1.3 & 87.2 & 0.8 & 1,960 & 64 & 2,816 & 60 & 35.0 & 0.20 \\
\hline Wholesale trade & 82.5 & 1.1 & 84.3 & 0.7 & 1,838 & 58 & 2,642 & 65 & 34.5 & 0.25 \\
\hline Finance, real estate & 83.1 & 0.8 & 85.5 & 0.7 & 2,019 & 43 & 2,844 & 49 & 36.0 & 0.25 \\
\hline Retail trade & 59.9 & 1.0 & 71.2 & 0.9 & 899 & 24 & 2,107 & 30 & 33.6 & 0.16 \\
\hline Professional services & 74.7 & 0.5 & 80.1 & 0.4 & 1,757 & 29 & 2,938 & 34 & 36.0 & 0.11 \\
\hline Other services & 48.8 & 1.0 & 66.2 & 1.0 & 792 & 29 & 2,454 & 46 & 33.9 & 0.15 \\
\hline
\end{tabular}


Table Three, continued

Eligibility, Take-Up, and Average Tax Subsidy Per Employee, By SelectedEstablishment Characteristics, 2008

\author{
Percent of \\ Percent of
}

Average tax

employees eligible eligible employees

for coverage

enrolled

Average tax subsidy

ubsidy per covere

Estimate

Estimate

per employee (\$)

employee (\$)

Census Division

New England

Middle Atlantic

East North Central

West North Central

South Atlantic

East South Central

West South Central

Estimate

Estimate

Tax subsidy as percent of

premiums

Mountain

Pacific

$\begin{array}{ll}70.8 & 1.2 \\ 70.4 & 1.0 \\ 68.7 & 1.1 \\ 67.7 & 0.9 \\ 70.0 & 0.8 \\ 67.8 & 1.3 \\ 64.9 & 1.4 \\ 64.9 & 1.1\end{array}$

$\begin{array}{ll}77.8 & 0.9 \\ 78.6 & 0.8 \\ 78.2 & 0.7 \\ 78.5 & 0.8 \\ 76.9 & 0.7 \\ 77.3 & 1.0 \\ 79.0 & 1.3 \\ 76.4 & 0.9 \\ 83.0 & 0.6\end{array}$

$\begin{array}{ll}1,750 & 54 \\ 1,594 & 42 \\ 1,511 & 39 \\ 1,477 & 57 \\ 1,402 & 34 \\ 1,306 & 40 \\ 1,181 & 40 \\ 1,239 & 36 \\ 1,521 & 37\end{array}$

$\begin{array}{ll}3,176 & 50 \\ 2,882 & 44 \\ 2,812 & 43 \\ 2,781 & 78 \\ 2,605 & 38 \\ 2,493 & 41 \\ 2,304 & 44 \\ 2,499 & 41 \\ 2,658 & 41\end{array}$

SE Estiamte

Source: Authors' calculations using data from the Medical Expenditure Panel Survey Insurance Component(MEPS-IC), Hous ehold

Component(MEPS-HC).

Notes:

1. Estimates were constructed using worker-level, not establishment, sampling weights.

2. Standard errors reflect sampling error in MEPS-IC. No adjustment is made for sampling variation in constructing synthetic workforces.

3. The MEPS-IC contains data on 31,073 private establishments after excluding railroads because of concerns involving confidentiality.

4. Each establis hment may have their own definition of "full time”.

5. In the 2008 MEPS IC, wage categories are defined (in $\$ 2008$ ) as follows: low wage $<\$ 11.00$ per hour; mediumwage $\$ 11.00$ to $<$

\$25.50 perhour; high wage \$25.50, or more perhour. 
Table Four: Multivariate Analysis of Average Tax Subsidies in Private Establishments, 2008

\begin{tabular}{|c|c|c|c|c|c|c|}
\hline \multirow[b]{3}{*}{ Intercept } & \multicolumn{3}{|c|}{$\begin{array}{l}\text { (1) Average tax subsidy } \\
\text { per employee (\$) }\end{array}$} & \multicolumn{3}{|c|}{$\begin{array}{l}\text { (2) Average tax subsidy } \\
\text { per covered employee (\$) }\end{array}$} \\
\hline & \multicolumn{2}{|l|}{ Estimate } & \multirow{2}{*}{$\begin{array}{l}\mathrm{SE} \\
64\end{array}$} & \multicolumn{2}{|c|}{ Estimate } & \multirow{2}{*}{$\begin{array}{l}\text { SE } \\
72\end{array}$} \\
\hline & 2,201 & $* *$ & & 3,136 & $* *$ & \\
\hline \multicolumn{7}{|c|}{ Firm size (reference $=1000$, or more, employees) } \\
\hline$<10$ & -941 & $* *$ & 27 & -571 & $* *$ & 40 \\
\hline $10-24$ & -724 & ** & 32 & -622 & ** & 46 \\
\hline 25-99 & -574 & ** & 30 & -554 & ** & 38 \\
\hline 100-999 & -313 & $* *$ & 32 & -280 & $* *$ & 37 \\
\hline \multicolumn{7}{|c|}{ 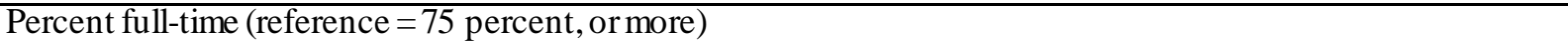 } \\
\hline$<25 \%$ & -794 & $* *$ & 46 & -366 & $* *$ & 72 \\
\hline $25-49 \%$ & -627 & ** & 33 & 65 & & 48 \\
\hline $50-74 \%$ & -434 & $* *$ & 32 & -144 & $* *$ & 45 \\
\hline \multicolumn{7}{|c|}{ Wage rate (reference $=>50 \%$ high wage) } \\
\hline$>50 \%$ low wage & -958 & $* *$ & 49 & -729 & $* *$ & 54 \\
\hline$>50 \%$ medium wage & -517 & $* *$ & 44 & -419 & $* *$ & 47 \\
\hline Other firms & -583 & $* *$ & 54 & -406 & $* *$ & 63 \\
\hline \multicolumn{7}{|c|}{ Industry (reference = other services) } \\
\hline Agriculture, fisheries, forestry & 52 & & 108 & -322 & & 206 \\
\hline Mining, manufacturing & 703 & ** & 50 & 194 & ** & 61 \\
\hline Construction & 65 & & 48 & -112 & & 64 \\
\hline Utilities, transportation & 664 & ** & 68 & 199 & ** & 77 \\
\hline Wholesale trade & 552 & ** & 61 & 88 & & 74 \\
\hline Financial services, real estate & 580 & $* *$ & 52 & 127 & $* *$ & 64 \\
\hline Retail trade & 47 & & 35 & -314 & ** & 49 \\
\hline Professional services & 525 & ** & 40 & 309 & ** & 55 \\
\hline \multicolumn{7}{|l|}{ Census division (reference = Pacific) } \\
\hline New England & 217 & ** & 52 & 489 & $* *$ & 60 \\
\hline Middle Atlantic & 43 & & 45 & 198 & ** & 54 \\
\hline East North Central & 27 & & 43 & 171 & ** & 54 \\
\hline West North Central & 49 & & 58 & 168 & * & 83 \\
\hline South Atlantic & -78 & & 41 & -33 & & 51 \\
\hline East South Central & -178 & ** & 41 & -142 & ** & 51 \\
\hline West South Central & -278 & ** & 45.6 & -297 & ** & 58 \\
\hline Mountain & -178 & ** & 42 & $-10^{*}$ & * & 52 \\
\hline $\mathrm{R}^{2}$ & 0.403 & & & 0.172 & & \\
\hline $\mathrm{N}$ & 31,073 & & & 19,439 & & \\
\hline \multicolumn{7}{|l|}{ Joint significance tests } \\
\hline Firm size & 351.57 & ** & & 84.11 & $* *$ & \\
\hline Percent full-time & 165.42 & ** & & 13.49 & ** & \\
\hline Wage rate & 141.00 & ** & & 61.55 & $* *$ & \\
\hline Industry & 63.03 & ** & & 32.75 & ** & \\
\hline Census division & 18.64 & ** & & 27.92 & ** & \\
\hline
\end{tabular}

Source: Authors' calculations using data from the Medical Expenditure Panel Survey Insurance Component (MEPS-IC) and Household Component (MEPS-HC)..

Notes:

1. Models are weighted by (1) total number of workers and (2) total number of enrolled workers.

2. Standard errors reflect sampling error in MEPS-IC. No adjustment is made for sampling variation in constructing synthetic workforces.

4. Each establishment may have their own definition of "full time".

5. In the 2008 MEPS IC, wage categories are defined (in $\$ 2008$ ) as follows: low wage $<\$ 11.00$ per hour; medium wage $\$ 11.00$ to $<\$ 25.50$ perhour; high wage $\$ 25.50$, or more perhour.

$* \mathrm{P}<.05 ; * * \mathrm{P}<.01$ 
Appendix A:

Control Variables Used in the Statistical Matching of MEPS HC and MEPS IC

\begin{tabular}{lc}
\hline Variable Category & $\begin{array}{c}\text { Establishment } \\
\text { Characteristics } \\
\text { Level/Type of Information Used }\end{array}$ \\
\hline Sector & Private, State-local government ${ }^{2}$ \\
Establishment offers insurance? & Y/N indicator \\
Industry & 2-digit NAICS code \\
Location & Census region/division \\
Establishment size & number of employees, in ranges \\
Multi-establishment firm? & Y/N indicator \\
\hline \multicolumn{2}{l}{ Establishment Distribution of Workforce Characteristics ${ }^{3}$} \\
Level/Type of Information Used \\
\hline Sex & \% female \\
Age & \% more than 50 years old \\
Union & \% unionized \\
Wage & \% low, medium, high wage \\
Full/part time & \% working full time / part time \\
Insurance eligibility & \% eligible \\
Held coverage & \% holding insurance coverage \\
Plan type & \% enrolled in single, employeeplus one, family plans \\
\hline
\end{tabular}

Notes:

1. In the MEPS HC establishment characteristics are recorded for each worker's current main job. Establishment characteristics for current miscellaneous jobs are imputed.

2. Data are developed separately for Federal government workers because they are out of scope for the MEPS IC.

3. In the MEPS IC workforce characteris tics are directly reported at the establishment levelor are calculated from summary information reported by establishments. In the MEPS HC these characteristics are reported at the individual level. 
Appendix B1:

Private Sector Worker Characteristics, 2008: Comparis on of Estimates from the MEPS IC and HC

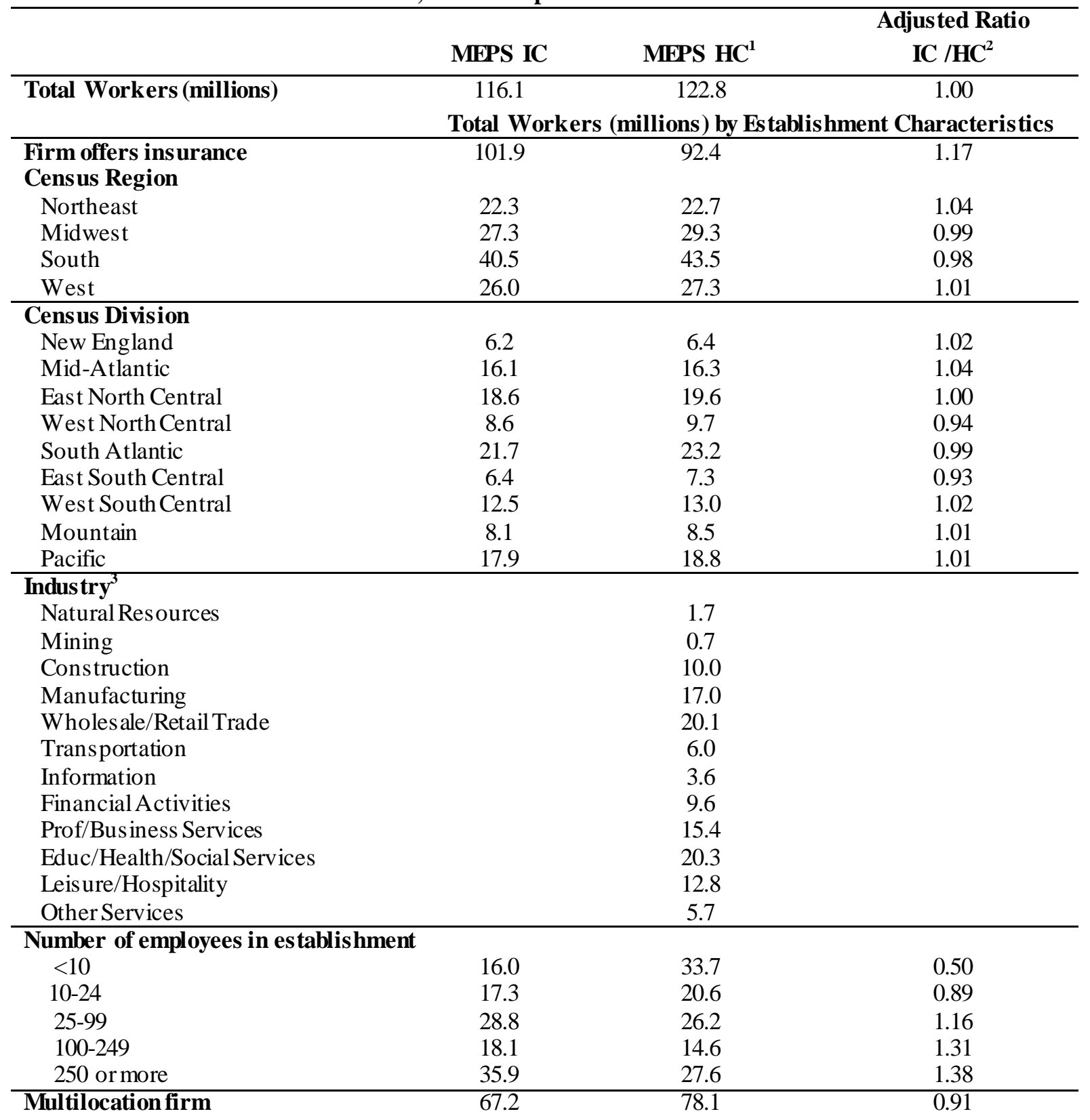


Appendix B1: Continued,

Private Sector Worker Characteristics, 2008 Comparis on of Es timates from the MEPS IC and HC

Adjusted Ratio

MEPS IC

MEPS HC

IC /HC

Total Workers (millions) by Workforce Characteristics

\begin{tabular}{lccc}
\hline Socioeconomic variables & & & \\
Female & 55.9 & 55.6 & 1.06 \\
Age 50 or older & 28.9 & 31.8 & 0.96 \\
Union member & 8.7 & 9.1 & 1.01 \\
Fulltime & 92.8 & 92.2 & 1.06 \\
Low wage & 34.6 & 38.0 & 0.96 \\
Mediumwage & 56.3 & 56.3 & 1.06 \\
High wage & 25.2 & 28.5 & 0.94 \\
\hline Insurance Variables & & & 1.17 \\
Firm offers insurance & 101.9 & 92.4 & 1.07 \\
Eligible for insurance & 79.6 & 78.4 & 1.11 \\
Holds insurance & 62.6 & 59.5 & 1.13 \\
$\quad$ Single coverage & 31.4 & 29.5 & 1.10 \\
$\quad$ Non-single coverage & 31.2 & 30.0 & \\
\hline
\end{tabular}

Source: Author's calculations using data from the 2008 MEPS IC, and the 2005-07 MEPS HC.

Notes:

1. MEPS HC estimates are average annual totals for the years 2005-07.

2. In the adjusted ratio, MEPS HC estimates are adjusted to account for the difference in the es timate of total workers across the MEPS HC and IC (e.g., MEPS HC estimates are multiplied by (116.1/122.8).

3. MEPS IC estimates of total workers by detailed industries have not yet been cleared from the Census Res earch Data Center. 
Appendix B2:

State and Local Government Workers, 2008: Comparis on of Es timates from the MEPS IC and HC

\begin{tabular}{lccc}
\hline & MEPS IC & MEPS HC $^{\mathbf{1}}$ & $\begin{array}{c}\text { Adjusted Ratio } \\
\text { IC /HC }\end{array}$ \\
\hline Total Workers (millions of workers) & 19.6 & 20.9 & 1.00 \\
& Total Workers & (millions) by Establishment Characteristics \\
\hline Firm Offers Insurance & 19.6 & 20.0 & 1.05 \\
Census Region & & & 0.96 \\
Northeast & 3.6 & 4.0 & 1.07 \\
Midwest & 4.4 & 4.4 & 0.98 \\
South & 7.1 & 7.7 & 1.02 \\
West & 4.5 & 4.7 & 0.96 \\
\hline Census Division & & & 0.96 \\
New England & 0.9 & 1.0 & 1.10 \\
Mid-Atlantic & 2.7 & 3.0 & 1.07 \\
East North Central & 3.0 & 2.9 & 0.98 \\
West NorthCentral & 1.5 & 1.5 & 0.98 \\
South Atlantic & 3.6 & 3.9 & 0.98 \\
East South Central & 1.2 & 1.3 & 0.93 \\
West South Central & 2.3 & 2.5 & 1.07 \\
Mountain & 1.4 & 1.6 & NA \\
Pacific & 3.1 & 3.1 & NA \\
\hline Industry & & & \\
Educ/Health/Social Services & NA & 12.8 & 1.27 \\
Public Administration & NA & 5.7 & 1.73 \\
All Other & NA & 2.4 & 0.71 \\
\hline Number of employees in establishment & & & 0.47 \\
<10 & 2.5 & 2.1 & NA \\
10-24 & 3.4 & 2.1 & \\
25-99 & 4.1 & 6.2 & 3.2 \\
100-249 & 1.5 & 3.4 & \\
Firm or more & 8.2 & 7.1 & NA multiple locations \\
\hline
\end{tabular}




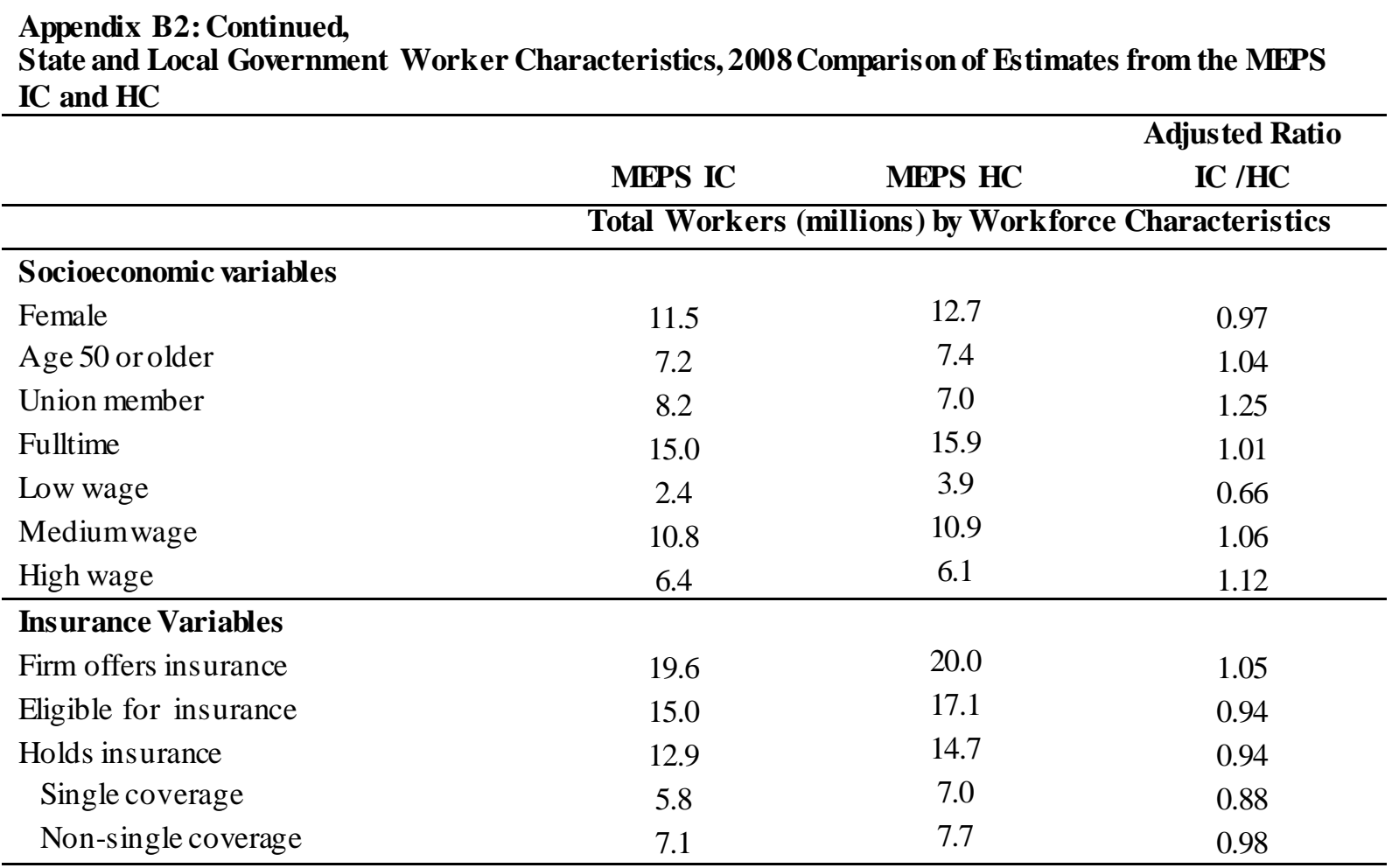

Source: Author's calculations using data from the 2008 MEPS IC, and the 2005-07 MEPS HC.

Notes:

1. MEPS HC estimates are average annual totals for the years 2005-07.

2. In the adjus ted ratio, MEPS HC estimates are adjusted to account for the difference in the es timate of total workers across the MEPS HC and IC (e.g., MEPS HC estimates are multiplied by (19.6/20.9). 


\section{Appendix C: \\ Derivation of Expressions for the Tax Subsidy and the Tax Price for Employer-Sponsored Health Insurance}

\section{Tax Subsidy:}

Total compensation (TC) paid by employers for each employee covered by employersponsored health insurance includes wages (W), health insurance premiums (P) and the employer share of Social Security/Medicare, taxes:

(1) $\mathrm{TC}=\mathrm{W}\left[1+\mathrm{t}^{\mathrm{SS}}\right]+\mathrm{P}$

In our estimates of the tax subsidy, we assume that employees who hold coverage bear the incidence of employer contributions in the form of lower cash wages. Employers minimize costs by paying benefits in the form of cash wages and premium contributions, per workers' preferences, subject to the constraint that total compensation does not change. This results in a wage-premium tradeoff in which wages fall by less than $\$ 1$ for each $\$ 1$ increase in premiums:

(2) $\mathrm{dTC}=0 \Rightarrow \frac{\mathrm{dW}}{\mathrm{dP}}=\frac{-1}{\left[1+\mathrm{t}^{\mathrm{SS}}\right]}$

Following our incidence assumption, we use workers' marginal tax rates for Federal taxes $\left(\mathrm{t}^{\mathrm{FED}}\right)$, state taxes $\left(\mathrm{t}^{\mathrm{ST}}\right)$ and the employer and employee share of Social Security/Medicare taxes $\left(2 * \mathrm{t}^{\mathrm{SS}}\right)$ to value the subsidy. Total taxes on each worker's wages are:

(3) $\operatorname{Tax}=\mathrm{W}\left[\mathrm{t}^{\mathrm{FED}}+\mathrm{t}^{\mathrm{ST}}+2 * \mathrm{t}^{\mathrm{SS}}\right]$

The change in tax revenues resulting from a change in premiums is:

(4) $\frac{d \operatorname{Tax}}{\mathrm{dP}}=\frac{\mathrm{dW}}{\mathrm{dP}}\left[\mathrm{t}^{\mathrm{FED}}+\mathrm{t}^{\mathrm{ST}}+2 * \mathrm{t}^{\mathrm{SS}}\right]$ 
Finally, substituting the expression for dW/dP from Equation 2 into Equation 4 gives us the per capita tax expenditure or the change in tax revenues for Federal and state governments, due to a change in premiums:

(5) $\frac{\mathrm{dTax}}{\mathrm{dP}}=-\left[\frac{\left(\mathrm{t}^{\mathrm{FED}}+\mathrm{t}^{\mathrm{ST}}+2 * \mathrm{t}^{\mathrm{SS}}\right)}{\left(1+\mathrm{t}^{\mathrm{SS}}\right)}\right]$

I ne per capita tax subsiay is simply -1 times the expression in Equation 5.

\section{Tax Price :}

The "tax price" of health insurance for workers, which formalizes the cost of insurance in terms of the after-tax consumption of spending a dollar on premiums, is equal to 1 minus the tax subsidy, or:

(6) Tax Price $=\left[\frac{\left(1-t^{\mathrm{FED}}-\mathrm{t}^{\mathrm{ST}}-\mathrm{t}^{\mathrm{SS}}\right)}{\left(1+\mathrm{t}^{\mathrm{SS}}\right)}\right]$ 